Article

\title{
Production and Application of Pectinases from Aspergillus niger Obtained in Solid State Cultivation
}

\author{
Ivana Greice Sandri * and Mauricio Moura da Silveira \\ University of Caxias do Sul, PO Box 1352, Caxias do Sul 95070-560, Brazil; mmsilvei@ucs.br \\ * Correspondence: ivana.sandri@hotmail.com; Tel.: +55-54-3027-3042
}

Received: 22 March 2018; Accepted: 9 July 2018; Published: 11 July 2018

\begin{abstract}
In this study, different concentrations of the inducer (pectin) and the carbon source (glucose) were evaluated as components of the culture medium for the production of pectinases by Aspergillus niger. Furthermore, it evaluated the stability of the enzymes produced with respect to the temperature and the enzyme extract produced was tested for the clarification of strawberry juice. The highest pectinolytic activity $(68 \mathrm{U} / \mathrm{g})$ was obtained at a concentration of $6 \%(w / w)$ of pectin in the absence of glucose in the medium. Pectinases activity has shown high stability at $20^{\circ} \mathrm{C}$ and $30{ }^{\circ} \mathrm{C}$ while a gradual decrease of activity was observed when the temperature rose. A reduction of about $50 \%$ of the total pectinases activity was measured at $50{ }^{\circ} \mathrm{C}$ after $60 \mathrm{~min}$ of exposure. The experimental enzymatic extract was compared with a high-quality commercial product for the clarification of strawberry juice. Similar data were obtained for turbidity and viscosity reduction. The enzymatic treatment led to a reduction of about $60 \%$ in the turbidity and $40 \%$ in the viscosity of the juice. After the enzymatic treatment, the total phenolic compounds, total anthocyanins, and antioxidant activity were preserved. The results obtained in the present work indicate the potential of the enzymes produced for using in fruit processing.
\end{abstract}

Keywords: pectin; glucose; pectinases; thermo-stability; strawberry juice

\section{Introduction}

Pectinolytic enzymes, which are also referred to as pectinases, include a group of enzymes that are responsible for the degradation of pectic substances and have important applications in the food industry [1,2]. Pectinases are important enzymes for the biotechnological sector, which have been presenting a constant increase in their market share and presently hold a leading position among the commercially-produced industrial enzymes [3]. These enzymes can be efficiently produced by both submerged and solid-state cultivation especially by fungi belonging to the genus Aspergillus. Solid-state cultivation (SSC) offers the possibility of processing agro-industrial residues that can be used, for instance, as substrates for enzyme production, which reduces the processing cost and environmental impact caused by these residues. SSC is a type of process that occurs in the absence or near absence of any liquid in the space among particles. In this system, water is present in the solid substrate whose capacity for liquid retention varies with the type of material [4].

Fungi have been considered the organisms most adapted to SSC because their hyphae can grow on particle surfaces and penetrate into the inter-particle spaces and, thereby, colonize solid substrates [5]. SSC generally employs a natural raw material as a carbon and energy source. Moreover, SSC can employ an inert material as the solid matrix, which requires supplementing a nutrient solution containing the necessary nutrients as well as a carbon source [6].

Fontana et al. [6] reported that an excess of glucose in solid media reduced the formation of polygalacturonases (PG) and hydrolases belonging to the pectinases group by a strain of 
Aspergillus niger. Teixeira et al. [7] described a repression of endo-PG and exo-PG production in Aspergillus japonicus when concentrations of glucose, pectin, and sucrose were above certain levels.

A. niger pectinases are the most widely used in industries because these species have the GRAS (generally regarded as safe) status so that the metabolites produced by this strain can be safely used [8]. Considering the promising opportunities that this species might offer to the food industry, the present study was carried out to assess the production of pectinases by A. niger LB-02-SF in experiments carried out with different pectin and glucose concentrations. Furthermore, the stability of these enzymes was evaluated at temperatures from $20^{\circ} \mathrm{C}$ to $70{ }^{\circ} \mathrm{C}$ and the enzymatic extract was evaluated for treating strawberry juice.

\section{Materials and Methods}

\subsection{Microorganism}

A. niger LB-02-SF from the culture collection of the Institute of Biotechnology of the University of Caxias do Sul (Brazil) was used in the experiments. The strain was propagated in glycerin agar medium and incubated at $30^{\circ} \mathrm{C}$ for five days. After this period, the sporulated cultures were stored at $4{ }^{\circ} \mathrm{C}$ or used for the inoculation of culture media.

\subsection{Culture Media}

The solid medium defined by Fontana et al. [6] was used as the basis for the experiments described in this work. The solid medium had the following composition (\%): wheat bran (MOINHO NORDESTE, Antonio Prado, Brazil), 36.6, citric pectin (CP KELCO S.A., Limeira, Brazil), 6.0 and salt solution, 36.6. The formulation of salt solution $(\mathrm{g} / \mathrm{L})$ was: $\left(\mathrm{NH}_{4}\right)_{2} \mathrm{SO}_{4}, 4.0, \mathrm{MgSO}_{4}, 1.0, \mathrm{KH}_{2} \mathrm{PO}_{4}, 2.0$, $\mathrm{FeSO}_{4} \cdot \mathrm{H}_{2} \mathrm{O}, 6.3 \times 10^{-4}, \mathrm{ZnSO}_{4}, 6.3 \times 10^{-4}$, and $\mathrm{MnSO}_{4}, 1.0 \times 10^{-5}$. The initial moisture was adjusted to $63 \%$ by adding distilled water and the medium was then autoclaved at $1 \mathrm{~atm}$ for $20 \mathrm{~min}$.

The production of total pectinases was performed in flasks. The evaluation of the pectin concentration $(0 \% w / w, 2 \% w / w, 6 \% w / w, 10 \% w / w, 12 \% w / w, 16 \% w / w, 20 \% w / w$, and $25 \%$ $w / w)$ on the pectinase production was assessed in medium containing $10 \% w / w$ of glucose while the tests on the influence of glucose concentration $(0 \% w / w, 5 \% w / w, 10 \% w / w, 15 \% w / w$, and $20 \% w / w)$ was performed with an initial pectin concentration of $6 \% w / w$. As the different amounts of pectin and glucose were added to the solid medium, a corresponding mass of wheat bran was reduced.

\subsection{Experimental Conditions}

Flasks $(100 \mathrm{~mL})$ containing $12 \mathrm{~g}$ of medium were used for the cultivation of $A$. niger and to produce enzymatic extracts. The flasks were inoculated with $A$. niger spores in order to have an initial concentration of $1.10^{7}$ spores $/ 100 \mathrm{~g}$ and were incubated at $30^{\circ} \mathrm{C}$ in a humidity-saturated environment for $72 \mathrm{~h}$.

The extraction of enzymes from solid media was carried out by suspending $1.0 \mathrm{~g}$ of dry material in $15 \mathrm{~mL}$ of distilled water ( $\mathrm{pH} 4$ ) by using 125-mL Erlenmeyer flasks that were agitated in a reciprocal shaker at $200 \mathrm{rpm}$ and $30^{\circ} \mathrm{C}$ for $60 \mathrm{~min}$. The enzymatic extract was obtained by centrifugation for 10 $\min$ at $5000 \times g$. The supernatant was stored at $4{ }^{\circ} \mathrm{C}$ for subsequent tests [6].

The thermo-stability of $A$. niger LB-02-SF pectinases was evaluated at temperatures from $20^{\circ} \mathrm{C}$ to $70{ }^{\circ} \mathrm{C}$. In these tests, the crude enzyme solution $(10 \mathrm{~mL})$ was submitted to each temperature and evaluated for up to $150 \mathrm{~min}$. The samples were collected every $15 \mathrm{~min}$ during the first hour of the test and then collected at every $30 \mathrm{~min}$.

The crude extract obtained from the cultivation process was concentrated before its application in strawberry juice treatment. Initially, the extract was pre-treated with activated charcoal $(5 \mathrm{~g} / \mathrm{L})$, microfiltered $(0.2 \mu \mathrm{m})$, and then concentrated by ultrafiltration using a membrane of nominal molecular weight cut-off of $10 \mathrm{kDa}$ [9]. 
Strawberries (Fragaria $x$ ananassa Duch.) were purchased at commercial maturity from a local supplier. The fruits were washed with tap water and processed in a domestic blender (WALITA, São Paulo, Brazil). The strawberry juice was then distributed into equal parts in test tubes and then subjected to three experimental enzymatic clarification treatments, which include the control in which the enzyme preparations were replaced by distilled water, the application of the experimental enzymatic extract, and the application of the commercial enzymatic preparation Pectine ${ }^{\circledR} \mathrm{Clear}$ (NOVOZYMES LATIN AMERICA LTD, Araucária, Brazil). The experimental enzyme extracts as well as the commercial preparation were diluted to 1 unit (U) of total pectinases per mL, which was previously standardized by Sandri et al. [1]. The enzymatic treatment assays were performed in a thermostatic bath (B. BRAUN BIOTECH model CERTOMAT WR, Melsungen, Germany), at $50{ }^{\circ} \mathrm{C}$ for a reaction time of $60 \mathrm{~min}$.

\subsection{Analytical Methods}

Total pectinases (TP) activity was determined by measuring the viscosity reduction of a standard solution of citric pectin (ESKISA S.A., São Paulo, Brazil) in $0.05 \mathrm{M}$ acetate buffer $\mathrm{pH} 4.0$ at $30^{\circ} \mathrm{C}$ for $30 \mathrm{~min}$. One TP unit was defined as the quantity of the enzyme that causes a $50 \%$ reduction in the solution viscosity under standardized conditions [10].

Pectinlyase (PL) activity was estimated by measuring the increase in absorbance at $235 \mathrm{~nm}$ due to the formation of unsaturated products, which was proposed by Albersheim [11]. The molar extinction coefficient of unsaturated products ${ }^{\mathrm{e}} 235=5550 \mathrm{M}^{-1} \mathrm{~cm}^{-1}$ was used to calculate enzymatic activity, $\mathrm{PL}=\left(\Delta \mathrm{A} /{ }^{\mathrm{e}} 235\right) \cdot 10^{6}(\mu \mathrm{mol} / \mathrm{mL} / \mathrm{min})$, where $\Delta \mathrm{A}$ represents the increase in absorbance per minute.

Pectin methylesterase (PME) activity was determined by the titration of carboxylic groups liberated through de-esterification of citric pectin, according to the method described by Duvetter et al. [12]. During pectin hydrolysis, the $\mathrm{pH}$ was maintained at a $\mathrm{pH}$ of 4.5 (set-pH) by adding $0.01 \mathrm{~N}$ $\mathrm{NaOH}$ using an automatic $\mathrm{pH}$-stat titrator (CONSORT model R735, Turnhout, Belgium). The activity unit $(\mathrm{U})$ of PME is defined as the amount of the enzyme required to release $1 \mu \mathrm{mol}$ of acid per minute under the aforementioned assay conditions.

Filter paper (FPase), endoglycanases, $\beta$-glucosidases, xylanases, and amylases activities were estimated based on the amount of carbohydrates released from Whatman $\mathrm{N}^{\circ} 1$ filter paper [13], carboxymethylcellulose (CMC) [14], salicin [15], xylan [16], and starch [17], respectively.

The concentrations of reducing sugars were estimated using the dinitrosalicylic method proposed by Miller [18].

The viscosity of the juice was measured with a viscometer (BROOKFIELD ENGINEERING, model DV-II+, Middleboro, USA) and turbidity was measured with a digital turbidity (MD-Digimed TU, São Paulo, Brazil) at room temperature.

Total soluble solids $\left({ }^{\circ}\right.$ Brix) were estimated by using a digital refractometer (model HI96801 HANNA Instruments, Cluj-Napoca, Romania) with automatic temperature compensation. $\mathrm{pH}$ was measured with a pH-meter (model DM-2, Digimed, São Paulo, Brazil). The titratable acidity was determined from $10 \mathrm{~mL}$ of distilled water-diluted juice $(1: 2 v / v)$ and titrated with $0.1 \mathrm{~N} \mathrm{NaOH}$ solution to $\mathrm{pH}$ 8.2. The titratable acidity is expressed as meq $\mathrm{NaOH} / 100 \mathrm{~mL}$ juice.

The total phenolic compounds (TP) were determined by the Folin-Ciocalteu procedure [19]. The phenolic content was expressed as gallic acid equivalents in $\mathrm{mg} \cdot 100 \mathrm{~mL}^{-1}$. The total anthocyanin (TA) was measured using the $\mathrm{pH}$ differential shift method [20]. The data are expressed as $\mathrm{mg}$ pelargonidin 3-glucoside (the most predominant anthocyanin in strawberry) per $100 \mathrm{~mL}$ juice (mg Pel3Glu/100 mL juice).

The free radical-scavenging activity was determined by ABTS $\left(2,2^{\prime}\right.$-azinobis [3-ethylbenzthiazoline]-6-sulfonic acid), which is a radical cation de-colorization assay described by Re et al. [21]. The results were corrected for dilution and expressed in mmol Trolox per $100 \mathrm{~mL}$ of juice. All determinations were performed in triplicate using a spectrophotometer (AURORA INSTRUMENTS, Vancouver, BC, Canada). 


\subsection{Statistical Analysis}

The data obtained were evaluated by the analysis of variance (ANOVA) followed by Tukey's pos-hoc test at a probability level of less than $5 \%(p<0.05)$. The results were presented as the mean with the respective standard deviation from two experiments under each cultivation condition and three experiments for other analyses. All tests were performed using the GraphPad Prism version 5.00 for Windows (GraphPad Software, San Diego, CA, USA).

\section{Results and Discussion}

\subsection{Effect of Pectin and Glucose Concentrations on the Solid-State Process}

The addition of $2 \%(w / w)$ to $10 \%(w / w)$ pectin to the medium resulted in the highest enzyme titers $\left(64 \mathrm{U} \cdot \mathrm{g}^{-1}\right)$. Above $10 \%(w / w)$ pectin, a reduction in the enzyme titers was measured possibly due to the compaction of the medium caused by an excess of the polysaccharide that could result in an inefficient mass and heat transfer (Figure 1). The solid cultivation medium is formed by small particles and has a large surface area that could be colonized by the microorganism. This characteristic can result in agglutination and hardening of the substrate, which, therefore, interferes with the aeration system and the use of oxygen by the microorganism [22]. The pectin could contribute to this situation. Furthermore, a high concentration of pectin may have impaired cell growth and enzyme production by lowering the amount of free water in the system. According to Demir and Tari [23], free water is an essential parameter for maximum enzymatic activity and the higher moisture contents favor the swell of wheat bran particles and increase the surface area. Moreover, the spaces between the swollen particles help vegetative growth and eventually increase the solubility of nutrients present in the wheat bran structure.
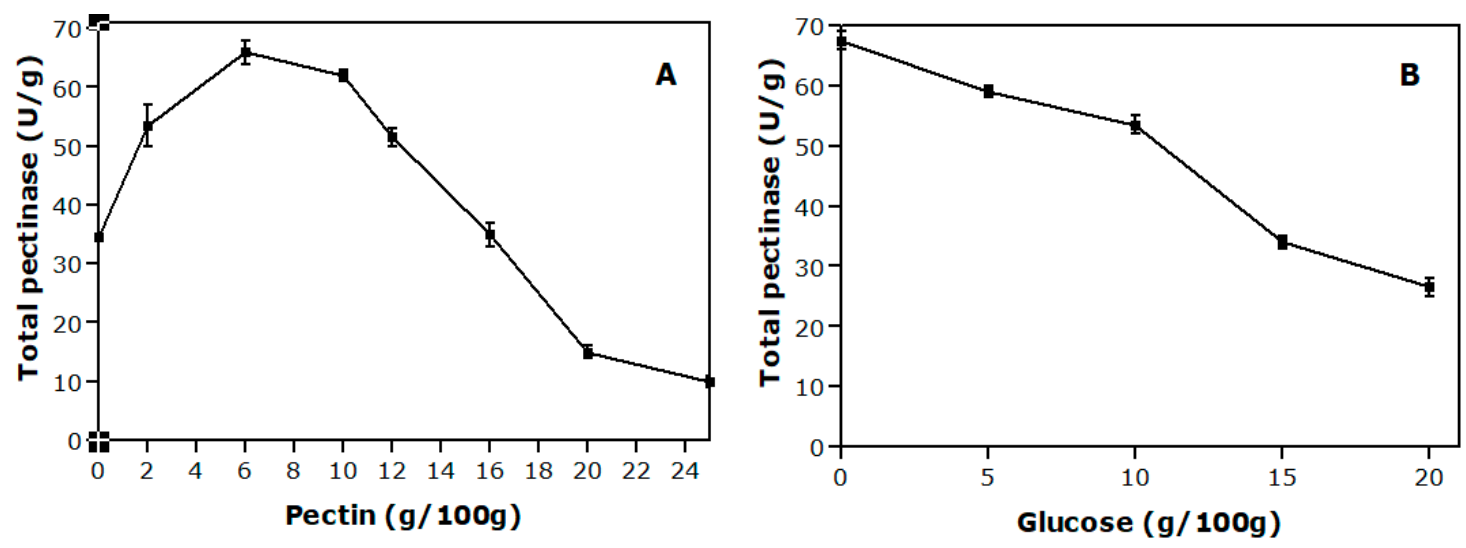

Figure 1. Variation of total pectinases activity in $72 \mathrm{~h}$ of cultivation of Aspergillus niger LB-02-SF with different concentrations of pectin and the initial glucose concentration of $10 \%(w / w)(\mathbf{A})$ and with different concentrations of glucose and initial pectin concentration of $6 \%(w / w)(\mathbf{B})$.

The process was then evaluated with different glucose concentrations in the medium. As shown in Figure 1B, higher enzyme titers $(68 \mathrm{U} / \mathrm{g}$ ) were obtained in the absence of this carbohydrate. In the presence of glucose, decreasing enzyme activities were measured when the concentration of glucose added to the medium was increased. It is possible that the presence of glucose caused a repressive effect on pectinase production. In addition, the absence of glucose may have limited the fungal growth and favored pectinases production. Poletto et al. [24] studied the pectinases production by A. niger LB-02-SF and have suggested that, under a growth-limiting condition, pectinase production is increased. Fontana et al. [6], while evaluating the production of endo-PG and exo-PG by A. niger T0005007-2 at different glucose concentrations, found that concentrations of up to $6 \%(w / w)$ of this carbohydrate resulted in a substantial increase in enzyme activity compared to the control (without 
glucose). The results showed that the composition of the pectinases production medium influences the pectinolytic activity. An optimized medium is required for each strain.

\subsection{Effect of the Temperature on the Stability of Pectinases}

Thermostability of an enzyme is the ability to resist thermal unfolding in the absence of substrates [2]. Knowing the behavior of each particular pectinase preparation with this knowledge is essential to defining the ideal condition of its use since the industrial application of these enzymes generally involve relatively high temperatures. Figure 2 depicts the effect of temperature from $20^{\circ} \mathrm{C}$ to $70{ }^{\circ} \mathrm{C}$ on the activity of pectinases of $A$. niger LB-02-SF for up to $150 \mathrm{~min}$. The enzymes present high thermo-stability at temperatures of $20^{\circ} \mathrm{C}$ and $30^{\circ} \mathrm{C}$. At $40{ }^{\circ} \mathrm{C}$, approximately $80 \%$ of the initial pectinolytic activity was preserved after $150 \mathrm{~min}$ of pre-incubation while decreasing activities were measured since larger temperatures were used in the tests. For $50{ }^{\circ} \mathrm{C}$, for example, a decrease of about $50 \%$ of the total pectinases activity was observed after $60 \mathrm{~min}$.

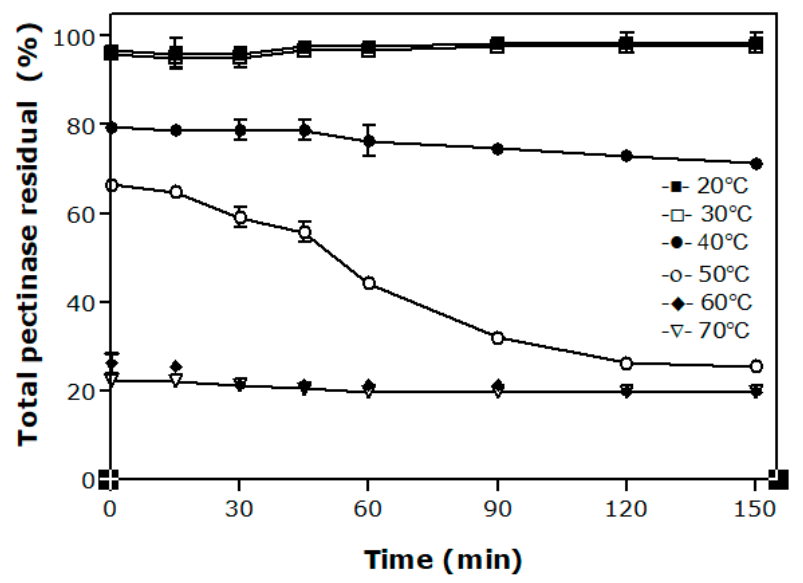

Figure 2. Effect of temperature and pre-incubation time on total pectinases activity of Aspergillus niger LB-02-SF.

From previous works found in the specialized literature, it was observed that thermo-stability varies depending on the enzymatic extract of each strain. Hendges et al. [25] evaluated the thermo-stability of endo-PG produced by A. niger T0005007-2 and observed a decrease of about $40 \%$ of the original activity when the preparation was exposed to $50{ }^{\circ} \mathrm{C}$ for $60 \mathrm{~min}$. For the same temperature and time, Ortega et al. [26] reported that the CCM commercial pectinase preparation held $57 \%$ of its initial activity while only $5 \%$ to $10 \%$ of the activities of Rapidase C 80 and Pectinex 3XL have been preserved. Cordeiro and Martins [27], when evaluating the polygalacturonase produced by a strain of Bacillus sp., defined the temperature of $70^{\circ} \mathrm{C}$ for $120 \mathrm{~min}$ as the optimum conditions for enzyme activity.

As already mentioned, pectinases are important enzymes especially for the fruit juice industry among other biotechnological applications. In fruit juice processing, before the addition of pectinases, the fruit is initially cooked and allowed to release most of the pectin into the juice, which results in a thick and cloudy appearance. Apples, stone fruits, and berries, for instance, are normally processed at $30{ }^{\circ} \mathrm{C}$ to $50{ }^{\circ} \mathrm{C}$ for about 15 to $90 \mathrm{~min}$ [28]. Therefore, considering the conditions commonly used for commercial enzymes, one can highlight the potential of the enzymatic extract produced by $A$. niger LB-02-SF for juice processing. 


\subsection{Application of the Enzyme Extract in Strawberry Juice Treatment and Characterization of the Enzyme Complex}

Enzymatic treatment is a key step in strawberry juice processing in order to remove the substances responsible for the turbidity of fresh juice and to prevent the turbidity development during storage, which is commonly known as haze formation. The crude enzyme extract produced by A. niger LB-02-SF was tested for the treatment of strawberry juice in comparison with the commercial preparation used as a reference. Table 1 presents the values for viscosity, turbidity, $\mathrm{pH}$, titratable acidity, total soluble solids, total anthocyanin (TA), total phenolic compounds (TP), and antioxidant capacity (AC) measured in strawberry juice with and without enzyme treatment. The enzymatic treatment of strawberry juice significantly reduced the turbidity and viscosity levels of the treated samples. The viscosity reduction process promotes more efficiency for juice processing since during the membrane filtration step, the fouling formation can be reduced, which results in an increasing permeate flux $[29,30]$. The enzymatic treatment of strawberry juice with the experimental enzyme preparation resulted in no significant difference in terms of turbidity or a viscosity decrease when compared to the treatment completed with the commercial product.

Table 1. Characteristics of untreated and enzyme-treated strawberry juices.

\begin{tabular}{cccc}
\hline \multirow{2}{*}{ Parameters } & Untreated Juice & \multicolumn{2}{c}{ Pectinases-Treated Juice } \\
\cline { 2 - 4 } & Control & Commercial Preparation & Experimental Preparation \\
\hline Viscosity (mPa.s) & $2898.67 \pm 263.44^{\mathrm{a}}$ & $999.34 \pm 110.40^{\mathrm{b}}$ & $1133.33 \pm 47.25^{\mathrm{b}}$ \\
Turbidity (NTU) & $2360 \pm 378.02^{\mathrm{a}}$ & $145.36 \pm 16.69^{\mathrm{b}}$ & $156.67 \pm 33.26^{\mathrm{b}}$ \\
pH value & $3.50 \pm 0.00^{\mathrm{b}}$ & $3.48 \pm 0.02^{\mathrm{b}}$ & $3.64 \pm 0.03^{\mathrm{a}}$ \\
Total soluble solids ( ${ }^{\circ}$ Brix) & $5.10 \pm 0.26^{\mathrm{b}}$ & $5.47 \pm 0.29^{\mathrm{ab}}$ & $6.00 \pm 0.20^{\mathrm{a}}$ \\
Titratable acidity & $7.66 \pm 0.57^{\mathrm{ab}}$ & $8.25 \pm 0.46^{\mathrm{a}}$ & $7.13 \pm 0.31^{\mathrm{b}}$ \\
(meq. NaOH/100 mL juice) & $18.44 \pm 1.61^{\mathrm{a}}$ & $16.84 \pm 1.76^{\mathrm{a}}$ & $17.76 \pm 1.83^{\mathrm{a}}$ \\
TA (mg Pel3Glu/100 mL juice) & $134.4 \pm 3.89^{\mathrm{a}}$ & $137.13 \pm 2.55^{\mathrm{a}}$ \\
TP (mg GAE/100 mL juice) & $140.10 \pm 4.13^{\mathrm{a}}$ & $1022.34 \pm 15.65^{\mathrm{a}}$ & $1027.00 \pm 17.39^{\mathrm{a}}$ \\
AC ( $\mu \mathrm{mol}$ TE/mL juice) & $1030.44 \pm 15.47^{\mathrm{a}}$ &
\end{tabular}

Different letters $(a, b)$ indicate significant differences $(p<0.05)$ for each analysis. The values correspond to the mean of three tests. TA, total anthocyanins content, Pel3Glu, pelargonidin 3-glucoside, TP, total phenolic compounds, GAE, gallic acid equivalent, AC, antioxidant capacity, TE, Trolox equivalent.

The $\mathrm{pH}$-value of untreated juice (control) and commercial-enzyme treated juices showed no significant difference after enzymatic treatment. Similar results were observed for titratable acidity and total soluble solids. The enzyme-treated juices showed a higher concentration of soluble solids especially in juices treated with the experimental enzyme preparation, which may be due to the release of sugars from the polygalacturonic acid chain during enzymatic hydrolysis. The application of the experimental preparation also affected $\mathrm{pH}$ and titratable acidity, which is possibly due to the chemical character of the monosaccharides and oligosaccharides released during the enzymatic treatment.

Epidemiological studies have repeatedly shown an inverse association between the risk of chronic human diseases and the consumption of a polyphenolic-rich diet. These compounds may be classified into different groups such as phenolic acids, flavonoids, stilbenes, and lignans [31].

Strawberries represent one of the most important sources of polyphenol compounds with antioxidant activity with other berries [32]. Therefore, it is important to note that the total polyphenolic, total anthocyanins, and the antioxidant capacity were not affected by enzymatic treatments, which is a behavior that was observed in other clarified fruit juices such as banana juice [33], blackberry juice [34], dragon fruit juice [35] and pomegranate juice [36]. In addition to the beneficial effects to health, the presence of the phenolic compounds are important from the commercial point of view because these substances have a potential food protecting capacity due to the antimicrobial and antioxidant activities. This increases the shelf-life of the product [37]. 
Anthocyanins are the most abundant flavonoid compounds in strawberries [38]. The anthocyanins concentration is dependent, among other factors, on the enzymes present in the enzymatic preparation (or extract) used for clarification. Glycosidases are enzymes that hydrolyze glycosidic bonds of the molecule. The stability of anthocyanins during clarification is of great importance. In addition to nutritional benefits, the presence of anthocyanins is related to the color and the color strongly affects the consumer choice.

In addition to pectinases, the experimental enzyme extract as well as the high-quality commercial preparation contain cellulases, $\beta$-glucosidases, xylanases, and amylases. The activities of these enzymes together contribute to the degradation of polysaccharides such as pectin, cellulose, hemicellulose, and starch, which are responsible for the turbidity and viscosity of juices [39]. FPase is an enzyme activity measurement that comprises the total cellulases (exoglucanases and endoglucanases) plus $\beta$-glucosidases activity. Endoglucanases act on the inner region of the cellulose chain and facilitate the extraction and maceration of fleshy fruits. Xylanases act on hemicellulose and help to reduce the turbidity of fruit juices. Amylases are particularly important in the processing of juices with a high concentration of starch such as apple juice $[28,40]$.

As shown in Table 2, TP activity in the experimental preparation presented no statistical difference in comparison with that the commercial product despite the relatively low PL titer. As TP activity represents a synergic action of the different pectinases, one can suppose that polygalacturonases play the most important role in this measurement. FPase activity in the experimental preparation was much lower than in Pectine ${ }^{\circledR}$ Clear. Considering the activities of endoglucanases and $\beta$-glucosidases in both enzyme preparations, it is admissible to consider that this difference was due to a low activity of exoglucanases (not determined), which are enzymes that are responsible for breaking cellulose crystallinity. This is an enzymatic action that is not particularly important in treating fruits. By their turn, xylanases and amylases activities were statistically identical in both experimental and commercial enzyme preparations.

Table 2. Total pectinases (TP), pectin methylesterase (PME), pectinlyase (PL), FPase, amylases, endoglucanases, xylanases, and $\beta$-glucosidases activities in experimental preparation and commercial preparation.

\begin{tabular}{ccc}
\hline Enzymes & Commercial Preparation $(\mathrm{U} / \mathrm{mL})$ & Experimental Preparation $(\mathrm{U} / \mathrm{mL})$ \\
\hline TP & $919^{\mathrm{a}}$ & $865^{\mathrm{a}}$ \\
PME & $3.3^{\mathrm{a}}$ & $3.7^{\mathrm{a}}$ \\
PL & $828^{\mathrm{a}}$ & $361^{\mathrm{b}}$ \\
FPase & $3.39^{\mathrm{a}}$ & $0.15^{\mathrm{b}}$ \\
Endoglucanases & $78^{\mathrm{a}}$ & $53^{\mathrm{b}}$ \\
$\beta$-glucosidases & $21^{\mathrm{a}}$ & $18^{\mathrm{a}}$ \\
Xylanases & $1411^{\mathrm{a}}$ & $1224^{\mathrm{a}}$ \\
Amylases & $45^{\mathrm{a}}$ & $38^{\mathrm{a}}$ \\
\hline
\end{tabular}

Values correspond to the average of three tests. Different letters $(a, b)$ indicate significant differences $(p<0.05)$ for each enzymatic activity.

\section{Conclusions}

In solid-state cultivation tests with A. niger LB-02-SF, it was found that $6 \%(w / w)$ of pectin in the culture medium and the absence of glucose favor the production of pectinases. The enzyme stability tests using temperatures up to $50^{\circ} \mathrm{C}$ indicate that the pectinolytic enzymes produced meet the process conditions required by the industry under this aspect.

Besides pectinases, the experimental enzyme preparation contains the most important hydrolytic enzymes that are responsible for the degradation of undesirable polysaccharides of fruit juices. Therefore, it is capable of significantly reducing the levels of turbidity and viscosity of strawberry juice without affecting the content of total phenolic compounds, anthocyanins, and antioxidant activity. The efficiency is comparable to a high-quality enzymatic formulation available in the market. 
The results obtained in this work confirm that the enzymes of $A$. niger LB-02-SF have high potential to be commercially used in the formulation of new products for fruit juice treatment. However, further studies must be carried out to optimize fungus cultivation and downstream processing conditions.

Author Contributions: I.G.S. designed and performed the experiments. M.M.d.S. analyzed the data.

Funding: The Universidade de Caxias do Sul (UCS) for the financial support of this work.

Acknowledgments: The authors acknowledge the Fundação de Amparo à Pesquisa do Estado do Rio Grande do Sul (FAPERGS), the Conselho Nacional de Desenvolvimento Científico e Tecnológico (CNPq), and the Universidade de Caxias do Sul (UCS) for the financial support of this work.

Conflicts of Interest: The authors declare no conflict of interest.

\section{References}

1. Sandri, I.G.; Fontana, R.C.; Barfknecht, D.M.; Silveira, M.M. Clarification of fruit juices by fungal pectinases. LWT Food Sci. Technol. 2011, 44, 2217-2222. [CrossRef]

2. Sandri, I.G.; Lorenzoni, C.M.T.; Fontana, R.C.; Silveira, M.M. Use of pectinases produced by a new strain of Aspergillus niger for the enzymatic treatment of apple and blueberry juice. LWT Food Sci. Technol. 2013, 51, 469-475. [CrossRef]

3. Xia, J.-L.; Li, P.-J. Pectic Enzymes. In Reference Module in Food Science; Elsevier: Amsterdam, The Netherlands, 2018.

4. Ruiz, H.A.; Rodríguez-Jasso, R.M.; Rodríguez, R.; Contreras-Esquivel, J.C.; Aguilar, C.N. Pectinase production from lemon peel pomace as support and carbon source in solid-state fermentation column-tray bioreactor. Biochem. Eng. J. 2012, 65, 90-95. [CrossRef]

5. Dos Santos, M.M.; da Rosa, A.S.; Dal'Boit, S.; Mitchell, D.A.; Krieger, N. Thermal denaturation: Is solid-state fermentation really a good technology for the production of enzymes? Bioresour. Technol. 2004, 93, 261-268. [CrossRef] [PubMed]

6. Fontana, R.C.; Salvador, S.; Silveira, M.M. Influence of pectin and glucose on growth and polygalacturonase production by Aspergillus niger in solid-state cultivation. J. Ind. Microbiol. Biotechnol. 2005, 32, 371-377. [CrossRef] [PubMed]

7. Teixeira, M.F.S.; Lima-Filho, J.L.; Durán, N. Carbon sources effect on pectinase production from Aspergillus Japonicus 586. Braz. J. Microbiol. 2000, 31, 286-290. [CrossRef]

8. Gummadi, S.M.; Panda, T. Purification and biochemical properties of microbial pectinases: Review. Process Biochem. 2003, 38, 987-996. [CrossRef]

9. Poletto, P.; Renosto, D.R.; Baldasso, C.; Zeni, M.; Silveira, M.M. Activated charcoal and microfiltration as pretreatment before ultrafiltration of pectinases produced by Aspergillus niger in solid-state cultivation. Sep. Purif. Technol. 2015, 151, 102-107. [CrossRef]

10. Gainvors, A.; Nedjaoum, N.; Gognies, S.; Muzart, M.; Nedjma, M.; Belarbi, A. Purification and characterization of acidic endo-polygalacturonase encoded by the PGLI-I gene from Saccharomyces cerevisiae. FEMS Microbiol. Lett. 2000, 183, 131-135. [CrossRef] [PubMed]

11. Albersheim, P. Pectin lyase from fungi. Methods Enzymol. 1966, 8, 628-631.

12. Duvetter, T.; Loey, A.V.; Smout, C.; Verlent, I.; Nguyen, L.B.; Hendrickx, M. Effect of temperature and pressure on the activity of purified tomato polygalacturonase in the presence of pectins with different patterns of methyl esterification. Innov. Food Sci. Emerg. Technol. 2005, 6, 293-303.

13. Camassola, M.; Dillon, A.J.P. Cellulase determination: Modifications to make the filter paper assay easy, fast, practical and efficient. J. Anal. Bioanal. Technol. 2012, 1, 1-4. [CrossRef]

14. Ghose, T.K. Measurement of cellulose activities. Pure Appl. Chem. 1987, 59, 257-268. [CrossRef]

15. Chahal, D.S. Solid-state fermentation with Trichoderma reesei for cellulose production. Appl Environ. Microbiol. 1985, 49, 205-210. [PubMed]

16. Bailey, M.J.; Biely, P.; Poutanen, K. Interlaboratory testing of methods for assay of xylanase activity. J. Biotechnol. 1992, 23, 257-270. [CrossRef]

17. Bansal, N.; Tewari, R.; Gupta, J.K.; Soni, R.; Soni, S.K. A novel strain of Aspergillus niger producing a cocktail of industrial depolymerising enzymes for the production of second generation biofuels. Bioresour. Technol. 2011, 6, 552-569. 
18. Miller, G.L. Use of dinitrosalicilic acid reagent for determination of reducing sugar. Anal. Chem. 1959, 31, 426-428. [CrossRef]

19. Singleton, V.L.; Rossi, J.A. Colorimetry of total phenolics with phosphomolybdic-phosphotungstic acid reagent. Am. J. Enol. Vitic. 1965, 16, 144-158.

20. Giusti, M.M.; Wrolstad, R.E. Characterization and measurement of anthocyanins by UV-visible spectroscopy. In Current Protocols in Food Analytical Chemistry; Wrolstad, R.E., Ed.; John Wiley \& Sons, Inc.: New York, NY, USA, 2001; p. F1.2.13.

21. Re, R.; Pellegrini, N.; Proteggente, A.; Pannala, A.; Yang, M.; Rice-Evans, C. Antioxidant activity applying an improved ABTS radical cation decolorization assay. Biochem. Eng. J. 1999, 26, 1231-1237. [CrossRef]

22. Pandey, A. Solid-state fermentation. Biochem. Eng. J. 2003, 13, 81-84. [CrossRef]

23. Demir, H.; Tari, C. Valorization of wheat bran for the production of polygalacturonase in SSC of Aspergillus sojae. Ind. Crops Prod. 2014, 54, 302-309. [CrossRef]

24. Poletto, P.; Polidoro, T.A.; Zeni, M.; Silveira, M.M. Evaluation of the operating conditions for the solid-state production of pectinases by Aspergillus niger in a bench-scale, intermittently agitated rotating drum bioreactor. LWT Food Sci. Technol. 2017, 79, 92-101. [CrossRef]

25. Hendges, D.H.; Montanari, Q.; Malvessi, E.; Silveira, M.M. Production and characterization of endo-polygalacturonase from Aspergillus niger in solid-state fermentation in double-surface bioreactor. Braz. Arch. Biol. Technol. 2011, 54, 253-258. [CrossRef]

26. Ortega, N.; Diego, S.; Perez-Mateos, M.; Busto, M.D. Kinetic properties and thermal behavior of polygalacturonase used in fruit juice clarification. Food Chem. 2004, 88, 209-217. [CrossRef]

27. Cordeiro, C.A.A.; Martins, M.L.L. Production of a polygalacturonase by thermophilic Bacillus sp. and some properties of the enzyme. Ciênc. Tecnol. Aliment. 2009, 29, 135-141. [CrossRef]

28. Sandri, I.G.; Piemolini-Barreto, L.T.; Fontana, R.C. Enzymes in Food Processing. In Biotechnology in Agriculture and Food Processing: Opportunities and Challenges, 1st ed.; CRC Press: Boca Raton, FL, USA, 2013; pp. $329-353$.

29. Echavarría, A.P.; Torras, C.; Pagán, J.; Ibarz, A. Fruit juice processing and membrane technology application. Food Eng. Rev. 2011, 3, 136-158. [CrossRef]

30. Maktouf, S.; Neifar, M.; Drira, S.J.; Baklouti, S.; Fendri, M.; Châabouni, S.E. Lemon juice clarification using fungal pectinolytic enzymes coupled to membrane ultrafiltration. Food Bioprod. Process. 2014, 92, 14-19. [CrossRef]

31. Ganesan, K.; Xu, B. A Critical Review on Polyphenols and Health Benefits of Black Soybeans. Nutrients 2017, 9, 1-17.

32. Tulipani, S.; Mezzetti, B.; Capocasa, F.; Bompadre, S.; Beekwilder, J.; De Vos, C.R.; Battino, M. Antioxidants, phenolic compounds, and nutritional quality of different strawberry genotypes. J. Agric. Food Chem. 2008, 56, 696-704. [CrossRef] [PubMed]

33. Lee, W.C.; Yusof, S.; Hamid, N.S.A.; Baharin, B.S. Effects of fining treatment and storage temperature on the quality of clarified banana juice. LWT Food Sci. Technol. 2007, 40, 1755-1764. [CrossRef]

34. Hager, T.J.; Howard, L.R.; Prior, R.L. Processing and storage effects on monomeric anthocyanins, percent polymeric color, and antioxidant capacity of processed blackberry products. J. Agric. Food Chem. 2008, 56, 689-695. [CrossRef] [PubMed]

35. Rahman, A.N.; Mazlina, M.K.S.; Taip, F.S. Impact of commercial pectolytic enzymes on selected properties of white dragon fruit juice. J. Inst. Eng. Malays. 2010, 71, 25-31.

36. Cerreti, M.; Liburdi, K.; Benucci, I.; Spinelli, S.E.; Esti, M. Optimization of pectinase and protease clarification treatment of pomegranate juice. LWT Food Sci. Technol. 2017, 82, 58-65. [CrossRef]

37. Velderrain-Rodríguez, G.R.; Quirós-Sauceda, A.E.; González Aguilar, G.A.; Siddiqui, M.W.; Ayala Zavala, J.F. Technologies in fresh-cut fruit and vegetables. In Minimally Processed Foods; Springer: Berlin, Germany, 2015; pp. 79-103.

38. Kovačević, D.B.; Putnik, P.; Dragović-Uzelac, V.; Vahčić, N.; Babojelić, S.M.; Levaj, B. Influences of organically and conventionally grown strawberry cultivars on anthocyanins content and color in purees and low-sugar jams. Food Chem. 2015, 181, 94-100. [CrossRef] [PubMed] 
39. Silva, D.; Tokuioshi, K.; da Silva Martins, E.; Da Silva, R.; Gomes, E. Production of pectinase by solid-state fermentation with Penicillium viridicatum RFC3. Process Biochem. 2005, 40, 2885-2889. [CrossRef]

40. Dhiman, S.S.; Garg, G.; Sharma, J.; Mahajan, R.; Methoxy. Characterization of statistically produced xylanase for enrichment of fruit juice clarification process. New Biotechnol. 2011, 28, 746-755. [CrossRef] [PubMed]

(C) 2018 by the authors. Licensee MDPI, Basel, Switzerland. This article is an open access article distributed under the terms and conditions of the Creative Commons Attribution (CC BY) license (http://creativecommons.org/licenses/by/4.0/). 